\title{
Integrated of Mobile Phone as Interactive Media in Extensive Listening
}

\author{
Abdul Kodir Al-Baekani ${ }^{1, *}$, Iwan Ridwan². \\ ${ }^{1}$ University of Singaperbangsa Karawang (UNSIKA), English Education Department, Karawang- \\ West Java, Indonesia \\ ${ }^{2}$ University of Singaperbangsa Karawang (UNSIKA), English Education Department, Karawang- \\ West Java, Indonesia
}

\begin{abstract}
Learning English is the most difficult to learn by students, especially in learning of listening aspect. This research aims to investigate the process of listening activity in the classroom using mobile phone as interactive media in extensive listening and how the students' responds of learning listening using mobile phone as an interactive media in extensive listening. Methodology of this research is descriptive qualitative. The subject of this research is Private Senior High School Muhammadiyah Karawang with 30 students as the sample of this research. The data analysis of this research uses the result of observation, interview, and documentation. Observation is used to know the learning process in classroom. Interview is used to know the students' respond in learning process. While documentation is used to strengthen the data. The result of observation class shows that the process of teaching and learning listening as follows: (1) the teacher begins learning within 10 minutes, (2) the main activity using mobile phone in learning listening within 25 minutes, and (2) the final activity: the teacher gives a test to measure the students' ability in listening comprehension. Meanwhile, the result of interview with the students shows that students mentioned convenience and interesting using mobile phone (37\%) and accessed in anywhere and anytime (30\%), easiness $(17 \%)$, authenticity (10\%), and usefulness and fun (7\%) to use their mobile phone in English listening.
\end{abstract}

Keywords : Extensive Listening, Interactive Media, Mobile Phone

\section{Introduction}

Listening is the most essential in communication. Human can speak verbally if they could listen. Al-Alwan (2013) argued that listening is the fundamental role on communication. In language, there are four basic skill that must be mastered by human to communicate each other. Firstly, listening is the first lesson that must be taught to students. Why is listening aspect should be the first lesson because as logically, human can be able to speak if they could listen something. Secondly is speaking. Thirdly is reading and the last skill is writing. For all, listening skill can be called the hardest skill to learn by the teacher or student because it is needed practice in learning.

Every school especially Senior High School, teacher should teach listening in the classroom and it should be practiced using media. Reinders, H., \& Cho, M. Y (2010) stated that Teachers and materials designers are starting to explore the potential of ubiquitous, relatively cheap and increasingly powerful devices as potential supports for learning and 
teaching. In reality, practicing in the classroom is rare because there is not media availability. Eventually, there is no specific strategy in learning listening in the university (MA, M. A. B., \& MA, C. T. M., 2014). Students learn listening section through speech teacher using English language in the classroom. Whereas, learning listening has to practice in learning process.

There are many learning media which can be used teacher to teach listening. One of them is Mobile Phone as a media. Rahmi (2015) clarified that mobile learning did have a significant effect on the listening comprehension ability. Almost all people especially teacher and student was using Mobile Phone which it was called Smart Phone. Every day, they use it to some necessity, such as necessity of communication, looking for information, and also for entertainment. Every human especially teacher and students got entertainment from Mobile Phone like listening music. Beside music, they also got listen the conversation even story and news using English language. In sum, English teacher in teaching listening material can use Mobile Phone as an interactive media in Extensive Listening.

From the problem above, researcher would like to try the research with the title "Integrated Mobile Phone as an Interactive Media in Extensive Listening.

The researcher limit this research, that is only learning process of English language listening section which it use Mobile Phone as an Interactive Media in Extensive Listening at Private Senior High School Muhammadiyah Karawang.

Based on limitation of the problem above, the formulation research question are as follows. (1) How does the English teacher use Mobile Phone as Interactive Media in Extensive Listening?; and (2)How are students' responses about using Mobile Phone as Interactive Media in Extensive Listening?.

There are two aims of this research as follows. (1) to know the process of learning English using Mobile Phone as Interactive Media in Extensive Listening; and (2) to know the students' responses about learning English using Mobile Phone as Interactive Media in Extensive Listening.

\section{Review of Related Literature}

\subsection{Extensive Listening}

Many reading researchers argued that extensive reading has an good essential to learn reading comprehension. In article of Willy A. Renandya, reading researchers (for example Adams 1998; Day and Bamford 1998) have now confirmed the importance of extensive reading in the acquisition of reading skills and that "reading is best learned through reading" (Adams op.cit.:73). The evidence for extensive reading is strong: it can improve students' word recognition skills, vocabulary, reading comprehension, fluency, and general language proficiency. In addition, students also develop more positive attitude towards reading and language learning in general. What is amazing is that the students obtain all these benefits by simply doing something that is pleasurable. They just read anything that they find enjoyable. The only condition is that they should choose reading materials that they can understand on their own and that they read a lot of these materials. In other words, they do a lot of practice in comprehension, not practice incomprehension as many EFL students often complain about their skills-or strategies-based reading lesson. In sum of them, extensive reading is a good way to improve reading comprehension skill. Wherever they are, whenever they are, they can do practice reading and it was not realized their skill in reading comprehension skill have increased.

Basically, the teachers have to know the principle of language learning and teaching. In handbook of Maya Pentcheva and Todor Shopov (2003:6) said that H. Douglas Brown 
notes in his Principle of Language Learning and Teaching that there are "...best of times and worst of times" in language teaching profession (Brown 1994a), we can safely say that this is the best of times for foreign language teacher. Today, we know much about foreign language acquisition, about child acquisition of language, about cognitive process, etc. it is also very important that we have come to an appreciation of the extreme complexity of this field. This gives us caution optimism to plunge even deeper into a problems.

In Indonesia, all of school especially in Senior High School, English is foreign language. The teachers teach English as a foreign language. They usually innovate to teach students better. Maya Pentcheva and Todor Shopov (2003:6) stated that foreign language teacher and educators are often confronted with the question "What method or what system do you use in teaching a foreign language?" Most often the answer does not come easily or if one gives a straightforward answer, he risks to be subjected to criticism. Teacher always have to make choices. These choices are motivated by the fact that they rest on certain Principles of language learning and teaching. Now that we know much more about on what we know about language itself. Often, swept by fashionable theories or a desire to sound "scholarly", we forget a simple truth - we, as human beings, teach a human language to human beings. "Students and teachers of language", says Osgood, "will discover the principles of their science in the universalities of humanness" (Osgood et al. 1957, 301). A concise but true in definition of man will probably include three major characteristics : (i) one who can reflected and interpret the world around him; (ii) one who can express feelings; and (iii) one who can use language. These characteristics underline three major principles of language teaching and learning.

From the explanation about the principle of language teaching and learning above, it seems to relate the principle of teaching listening in the classroom because many language learners assume that learning listening is difficult even it is the most difficult to learn. To understand better the difficulties in teaching listening, we should begin by identifying the difficulties the student faces when undergoing listening (Natasya Walker, 2014). A lot of learners think the most difficult in learning listening are lack vocabulary and pronunciation. The evidence of difficult in learning listening about pronunciation (Bloomfield et al 2010:3) was stated in article of Natasya Walker (2014) that "the pronunciation of words may also differ greatly from the way appear in print". With the acoustics of the spoken language often varying dramatically to the form of the written language, the identification of words that constitute the oral discourse could prove to be problematic for the students. Likewise, "listeners, unlike readers, do not have the luxury of regular spaces that signal where words begin or end" (Vandergrift, 2007:296). Besides that, lack vocabulary and grammar still become problem to teach listening. Osada (2004:59) in Natsya Walker (2014) stated that vocabulary and grammar also tend to be far more colloquial and much less formal than what the students may be accustomed to, making for potential confusion should their vocabulary knowledge not be familiar with such expressions, as "an obvious factor that can influence comprehension of spoken passage is the overlap between the listener's vocabulary knowledge and the vocabulary of the passage" (Bloomfield et al 2010:12).

In sum, teachers should innovate to teach listening in order to learn listening easier especially to improve students' vocabulary. Pronunciation also should be focused by the teacher with someway like extensive listening in the classroom. It is the way to increase listening comprehension skill. One of this way is using mobile phone to help the process of listening section in the classroom.

\subsection{Mobile Phone Media}

To make definition of mobile-assisted language learning (MALL) is complex because it should be understood about cultural, disciplinary, and temporal context. It sheds light on 
the problem of definitions. Which are often circular, insufficient, varying over time, and contradicted by different sources, by helping to distinguish which definition is more accurate, and why. Because, to a great extent, defining is contextualizing, this method can help to define subfield or concept in their fuller dimensionality (Steave McCarty et al. 2017). The example of MALL is technology-enhanced language learning (TELL) to help teacher in teaching using technology (e-learning). Because, each eras are different using technology in learning especially language learning. Steave McCarty et al. (2017) stated that TELL must also listed in chronological order, which helps to gauge the accuracy of many competing or completed definitions of terms: (a) distance education, which is still mostly correspondence education in practice around the world, (b) e-learning, which is still most widely to cover all forms of digital learning (including CD-ROMs in CALL Labs), and (c) online education, which is most recent and relies on the Internet for synchronous and/or asynchronous communication. Online education include blended learning, because use of the Internet is incorporated into such classes. In this era, e-learning always use computer in teaching language learning especially listening material. Listening section of language learning uses computer as a media to help teacher and students in the process of listening activity. In fact, many school do not have a lab or CALL (Computer-Assisted Language Learning). This is a problem that makes teacher confuse to solve it. But, there is a solution: using mobile phone in teaching and learning listening section.

From the explanation above about teaching and learning listening that should be available media to support teacher in teaching listening, it can be concluded that teaching listening has to use media. There are a lot of media which can be used by teacher to deliver material listening. One of them is Mobile Learning. Gautam (2014) stated that mobile learning is an effective way in the process of learning language. Listening skill is an ability to identify and understand what people said. This process involves understanding of phone or speaker's pronunciation, grammar and also vocabularies, and understood of meaning. An active listener will understand the meaning overall (Howat and Dakin, 1997). Listening ability for students using mobile phone media will make easier to understand and to learn listening skill.

The procedures of learning English using mobile phone are as follows : (1) teacher deliver indicator of learning which it was achieved, (2) teacher explain what should students do for the competence, (3) teacher divides students into group with the same skill, (4) teacher allows students to open android mobile phone with relevance topic, (5) teacher allows students to conclude about the content of recording on their mobile phone, (6) teacher concludes students' opinion, and (7) teacher make a concept of learning listening using mobile phone.

\section{Research Method}

The site of this study was a private school in Karawang, West Java. This school had a populations of more than 500 students with various sociocultural backgrounds. Most of students were bilingual (e.g. Bahasa Indonesia and Sundaness). Most students come from at the low-middle economic background; so, they are relatively highly motivated to learn English. This positive enthusiasm positively affects their engagement in the classroom. They are active and curious in learning, especially with innovative learning strategy, integrated Mobile Phone as an interactive media in extensive listening. We chose the site because of two considerations: (1) learning listening at this school was supported by Mobile Phone as an interactive media in extensive listening, and (2) the authors got an entry access to this school.

In order to accomplish this research, it is needed an appropriate research design. Since this research aims at exploring how Mobile Phone is used in teaching listening and to reveal 
students' responses toward the used Mobile Phone in teaching listening then basic interpretative \& phenomenological study are recommended one. It is in line with Ary, Jacobs, Sorensen \& Razavieh (2010) point out mentioned research design aims to describe phenomenon and to reveal subjects' perspective on what they experienced. This method can be called basic interpretative study.

The participants of the present study were 30 students in Private Senior High School Muhhammadiyah Karawang. These students were supported learning listening using Mobile Phone. They were given instruction by teacher to learn listening material using Mobile Phone, thus these students were chosen as participants of the research.

Mostly, the traditional pedagogical procedures to teaching listening is through a process of ; (1) the teacher presents a topic of listening material, (2) the teacher talks about the topic of material, (3) student listens what the teacher said, and (4) student looks for the words and translate them into Indonesian Language. In contrast, in this study, teaching procedure is outlined as follows. Students are working in a groups of two equipped with a unit of smartphone or Mobile Phone with the application which was shared by teacher to students. The apps that was used in this activity is English Listening Apps. They have been downloaded those application on their Mobile Phone. And also the topic or material of listening which should be listened by students, it was downloaded by them. Meanwhile, to test their skill in listening comprehension, teacher uses English Listening Test Apps. There are some steps done by the teacher to teach listening using mobile phone, as follows. (1) The teacher asked the students to open mobile phone application, then choose play store menu, and next is to download the English listening skill menu. After done, it can be transferred to other students by using share it menu; (2) the teacher taught the students about listening by using mobile phone. The theme about appointment. The teacher asked the students to have aural drill, then aural and oral drill. Next, they repeated it with their seatmates; (3) the teacher asked the students to summarize the content of the dialog they listened to; (4) the teacher concluded the listening subject they learn in mobile phone about appointment; and the final one (5) the teacher provided the English Listening Test on Mobile Phone with multiple choice type.

The data can be analysed through as follows. (1) Class Observation: The researcher observes learning activity in the classroom using Mobile Phone in teaching listening. The researcher observes the teacher from preparation in the class till end, such as, in the first activity with the duration of 10 minutes, the teacher did apperception, motivated the students, expalined the achieved goal of learning, and explained the steps of learning. Next, in the main activity within 25 minutes, the teacher teaches the studnets using mobile phone with the proper steps, such as the students observe the English lsitening material using mobile phone, the students practise aural and oral drill using mobile phone, the students summarize the content of the listening material from mobile phone. And in the final one, teachers tests the students using mobile phone to find out the result of learning process done in 10 minutes test. (2) Interview: it is proof against the information obtained previously. "Interview can be done in a structured and unstructured, and can be done face to face or using the phone"(Sugiyono, 2006; 138-140); and (3) Documentation: Sugiyono (2011:329-330) argued that documentation is a record of events that have already passed. The documentation can be shaped writing, pictures, or the monumental works from someone. Documentation in the from of images such as photos, videos and other sketches. Research result from observation or interviews, it would be more credible or trustworthy if supported by a personal history of childhood life, school, in workplace, in society and autobiography. The data will be needed by researchers is the form of notes non-statistical the profile, goals, lesson plan, syllabus, material, the photos at the time of learning, vision and mission of the school. 


\section{Findings}

Based on the result of analysis by using interviews for 30 participants or students showed that, as follows: (1) the favorite part in using the apps for the surdents on the mobile phone to improve listening skills indicated that most of the students responded positively. To be more specific, the students mentioned convenience and interesting using mobile phone (37\%) and accessed in anywhere and anytime (30\%), easiness $(17 \%)$, authenticity (10\%), and usefulness and fun (7\%) to use their mobile phone in English listening. (2) the responses of the second question, the least favorite aspects of using the mobile phone app, the students' ideas. The students mentioned 'preference using textbooks in class' $(50 \%)$, 'difficulty to understand' $(25 \%)$, and 'no scripts' $(25 \%)$. However, not many of the students showed negative aspects of using the mobile technology. (3) Based on the thirdly, how effective it is to use the mobile phone apps to develop listening skills, the result presents the responses. The detailed responses revealed that most participants'feedback focused on a variety of English expressions and vocabulary (33\%). The second most frequent response was 'good to have more chances to access English anytime anywhere' (27\%) and 'to be good for self-studying' (23\%). Furthermore, the students stated that they were able to have confidence in listening authentic materials $(17 \%)$; (4) From the last result that the points the students considered to be ineffective to use the mobile phone apps, the students' ideas. Not many responses to this question were elicited, as seen in Table 4. The responses of the ineffectiveness of using the apps were 'difficulty to understand' (40\%), and 'difficulty of speed' (60\%).

It can be concluded from the findings that the mobile phone app would be a more efficient way to expand English listening skills. In addition, mobile device allowed learners to integrate the world outside with the authentic materials and give more positive attitudes for language learning.

\section{Conclusion}

Based on the analysis of the questionnaire result that the favorite part in using the apps for the students on the mobile phone to improve listening skills indicated that most of the students $(\mathrm{N}=30)$ responded positively .To be more specific, the students mentioned convenience and interesting using mobile phone (37\%) and accessed in anywhere and anytime $(30 \%)$, easiness $(17 \%)$, authenticity $(10 \%)$, and usefulness and fun $(7 \%)$ to use their mobile phone in English listening. In return, the least favorite aspects of using the mobile phone app, the students $(\mathrm{N}=5)$ mentioned 'preference using textbooks in class' $(50 \%)$, 'difficulty to understand' $(25 \%)$, and 'no scripts' $(25 \%)$. However, not many of the students showed negative aspects of using the mobile technology. And, how effective it is to use the mobile phone apps for the students $(\mathrm{N}=30)$ to develop listening skills, the detailed responses revealed that most participants' feedback focused on a variety of English expressions and vocabulary (33\%), the second most frequent response was 'good to have more chances to access English anytime anywhere' (27\%) and 'to be good for selfstudying' (23\%), Furthermore, the students stated that they were able to have confidence in listening authentic materials $(17 \%)$. In reverse, the students $(\mathrm{N}=5)$ considered to be ineffective to use the mobile phone apps, not many responses to this question were elicited. The responses of the ineffectiveness of using the apps were 'difficulty to understand' (40\%), and 'difficulty of speed' $(60 \%)$.

In addition, the average result of listening test using mobile phone also showed positive result from the first session to final one. First test of average result was about 60,33 . The second one was about 65,33 , and the last one was about 73,83 . So, it can be concluded that using mobile phone can improve students' listening skill. 


\section{References}

1. Al-Alwan, A., Asassfeh, S., \& Al-Shboul, Y. EFL Learners' Listening Comprehension and Awareness of Metacognitive Strategies: How Are They Related?. International Education Studies, 6(9), 31. (2013).

2. Archana Gautam. Mobile Learning; an Effective Way of Teaching and Learning English Language, http://www.arcjournal.org (2010)

3. Bloomfield, A. et al.. What makes listening difficult? Factors affecting second language listening comprehension. (2010)

4. Brown, H. Douglas. Teaching by Principles: An Interactive Approach to LanguagePedagogy. 2 Edition.England: Pearson Longman. (2000).

5. Catherine Marhall, Gretchen B Rossman;Designing Qualitative Research, Second Edition. Sage Publications, International Educational and Professional Publisher, London, (1995).

6. Creswell, J. W. Qualitative inquiry and research design: Choosing among five designs. Thousand Oaks, CA: Sage. (1998).

7. Howatt, A., and J. Dakin. Language Laboratory Materials, ed. J.P.B Allen, and S.P. Corder. (1974)

8. Jack C. Richards. Communicative Language Teaching Today. (Cambridge University, Press 2006)

9. Maya Pentcheva and Todor Shopov, Whole Language, Whole Person: A Hanbook of Language Teaching Methodology, (Viseu, 2003)

10. Merriam, S. B. Qualitative research in practice: Examples for discussion and analysis. San Francisco, CA: Jossey-Bass. (2002).

11. MA, M. A. B., \& MA, C. T. M.. Listening comprehension difficulties encountered by students in second language learning class. Journal of Educational and Instructional Studies in the World, 3. (2014)

12. Natasya Walker. Listening: the most difficult skill to teach, 23 (2014).

13. Steave McCarty, Takehi Sato, and Hiroyuki Obari. Implementing Mobile Language Learning Technologies in Japan. (2017)

14. Rahimi, M., \& Soleymani, E. The impact of mobile learning on listening anxiety and listening comprehension. English Language Teaching, 8(10), 152. (2015).

15. Reinders, H., \& Cho, M. Y. Extensive listening practice and input enhancement using mobile phones: Encouraging out-of-class learning with mobile phones. (2010).

16. Sugiyono. Metode Penelitian Pendidikan (Pendekatan Kuantitatif, Kualitatif, danR\&D). Bandung: Alfabeta. 2011. 